\title{
Intellectual Capital, Bank Size, Bank Market Share, and Efficiency of Conventional Banks in Indonesia*
}

\author{
Capital intelectual, tamaño del banco, participación en el mercado bancario y \\ eficiencia de los bancos convencionales en Indonesia
}

\author{
Rahmat, SIP., M.H. \\ Student of Doctoral Program in Management Science, Universitas Pendidikan Indonesia, \\ Bandung -Indonesia, rahmat@ekuitas.ac.id
}

\begin{abstract}
How to cite / Cómo citar
Rahmat, S. M. (2020). Intellectual capital, bank size, bank market share, and efficiency of conventional banks in Indonesia. Revista CEA, 6(11), 71-88. https://doi.org/10.22430/24223182.1457
\end{abstract}

Received: 8 August 2019

Accepted: 30 September 2019

\begin{abstract}
This study aims to empirically examine the effect of intellectual capital, bank size, and market share on the efficiency of commercial banks in Indonesia from 2013 to 2017. The results of a panel data analysis of two models show that intellectual capital (calculated simultaneously or individually per component), bank size, and market share have a significant effect on bank efficiency, as confirmed by a fixed-effect regression model. Said model indicates that the year-to-year effect of the independent variables is influenced by individual bank differences. In other words, dissimilar characteristics of banks' intellectual capital and its components determine the effect of said variables on bank efficiency. Likewise, the asset ownership and market share of banks also distinguish their behavior in terms of bank efficiency.
\end{abstract}

Keywords: Intellectual capital, bank size, bank market share, bank efficiency.

JEL Classification: G21, L22, O16.

\footnotetext{
* This article is derived from a dissertation project entitled "Analysis of Bank Efficiency and Bank Stability (Stochastic Frontier Approach and Distribution-Free Approach Model for Indonesia Commercial Banks)" and has been funded with own resources.
} 


\section{Resumen}

Este trabajo tiene como objetivo estudiar empíricamente el efecto que el capital intelectual, el tamaño del banco y la participación en el mercado tuvieron sobre la eficiencia de los bancos comerciales en Indonesia entre 2013 y 2017. Los resultados de un análisis de datos de panel de dos modelos muestran que el capital intelectual (calculado de forma simultánea o individual por componente), el tamaño del banco y la participación en el mercado tienen un efecto significativo en la eficiencia bancaria, lo cual confirmó un modelo (regresión) de efectos fijos. Dicho modelo indica que la diferencia anual de las variables independientes está influenciada por las características particulares de las instituciones bancarias. En otras palabras, las diferentes características del capital intelectual de los bancos y sus componentes determinan el efecto de dichas variables en la eficiencia bancaria. Asimismo, los activos y participación en el mercado de los bancos distinguen su comportamiento en términos de eficiencia bancaria.

Palabras clave: capital intelectual, tamaño del banco, participación en el mercado bancario, eficiencia bancaria.

Clasificación JEL: G21, L22, O16.

\section{INTRODUCTION}

As financial institutions, banks play a strategic role in national economies through banking systems, receiving funds from the community (individuals and companies) and distributing them to individuals or companies in the form of loans (Allen \& Santomero, 1997; Song et al., 2018). Commercial banks in Indonesia are granted broader authority; namely, they can place public funds in the form of investments in securities and conduct activities in foreign currencies by fulfilling the conditions stipulated by Bank Indonesia (Shaban et al., 2014).

Given their vital role in a country's economy, banks are also required to operate efficiently. Bank efficiency is an important indicator to analyze the performance of a bank (Girardone et al., 2004). Astiyah and Husman (2006), claims that bank efficiency is not only important as an indicator in banking but also as a means to further enhance the effectiveness of monetary policy so that it can more effectively reach its target.

Bank efficiency in Indonesia has been strongly emphasized after the period of the enactment of the ASEAN Economic Community (MEA), during which Bank Indonesia (BI) issued Bank Indonesia Peraturan Bank Indonesia Nomor 14/26/2012 (Regulation Number 14/26/PBI/2012) concerning Business Activities and Office Networks Based on Bank Core Capital. Such regulation stipulates that the planned integration of the ASEAN financial sector in 2020, which began in 2015, allows banks with certain qualifications (Qualified ASEAN Banks, QAB) to operate freely in the ASEAN region; therefore, national banks need to improve their resilience, competitiveness, efficiency, and productivity.

Banking efficiency has attracted the interest of multiple researchers with various approaches. Among them, Astiyah and Husman (2006) examined the efficiency level of 20 banks with the largest assets in Indonesia using the stochastic frontier analysis method. The results of their research demonstrated 
that banks from foreign bank groups tend to be more efficient. The same situation occurred with the Regional Development Bank (BPD) group. Another finding from their research is that several banks, which calculated efficiency based on the intermediation emphasis model, exhibited high profits but were not efficient. This shows that such banks have not carried out the intermediary function properly; as a result, they do not optimally contribute to a broader economic growth.

Sudarsono (2009) conducted a study on the efficiency of conventional and Islamic banks in Indonesia using the ratio of operational costs to operating income (BOPO). He found that Islamic banks were more efficient. Conventional banks' BOPO was higher than $80 \%$ since 2005, while that of Islamic banks was under $80 \%$ since 2008. Even though ideally the BOPO should range between $60 \%$ and $80 \%$, conventional banks do not fulfill their revenue targets due to their high costs.

Another finding regarding the efficiency of shari'ah banking in Indonesia was reported by Faruk et al., (2017), who used the DEA method. They revealed that shari'ah banks underperformed in the 20092015 period, and managers were incompetent to use their input resources effectively even though they had achieved a fairly optimal operation before. In other words, Islamic banks in Indonesia operated inefficiently during said period.

From the various findings in bank efficiency studies in Indonesia in different periods of observation, it can be concluded that banks in Indonesia, still today, do not operate efficiently. Consequently, further research is needed regarding the factors that may cause bank efficiency.

Studies into factors that cause bank efficiency have been carried out before, but the results showed inconsistencies in the variables (Salem \& Rahman, 2016). Girardone et al., (2004) examined small and large-scale banks in Italy. The results of their research indicate that inefficiency is inversely correlated with the strength of capital and positively related with the level of non-performing loans. Their analysis also showed that there is no clear relationship between asset size and bank efficiency.

In contrast, Delis and Papanikolaou (2009) examined 364 banks in 10 countries that were new members of the European Union. They found that almost all the banks had increased their efficiency during the 1994-2005 period. Bank size, market concentration, and economic situation, according to them, are the factors that determine efficiency. Alhassan and Ohene-Asare (2016) examined 26 banks in Ghana during the 2004-2011 period and revealed that the variable interbank competition determines bank efficiency in Ghana. In addition to the level of competition, they found that company size, leverage, and non-interest income are other variables that may produce bank efficiency.

The results of those studies show that efficiency research is still focused on financial aspects, while non-financial ones have not been widely investigated. One of those non-financial aspects is intellectual capital (IC), which has been defined as an asset that can create value to help companies achieve and maintain their competitive advantage (Bontis, 2010; Kamath, 2008).

In line with those arguments, the present study aims to empirically examine the effect of intellectual capital on the efficiency of conventional commercial banks in Indonesia. 


\section{THEORETICAL FRAMEWORK}

\section{Intellectual Capital and Bank Efficiency}

Researchers have adopted a variety of perspectives to explore the factors that determine company performance. In this regard, Penrose in 1959, as cited in Rugman and Verbeke (2002), Kor and Mahoney (2004), and Newbert (2007) expressed their views through a widely known theory, namely, the Resource-Based View (RBV). The RBV theory suggests that corporate resources are heterogeneous and productive services derived from company resources provide each company with unique characteristics. If a company can make full use of its resources, and is able to compete with its competitors.

The resources referred to in the RBV theory have four characteristics:

1) They are able to support the company's ability to meet customer needs better than competing companies.

2) They are available in limited or rare quantities and are not easily replicated. Four situations cause resources to be difficult to imitate: (a) those resources are physically unique, (b) they require a long time and a large cost to obtain them, (c) unique resources that are difficult for competitors to use and take advantage of, and (d) resources that require large capital investments to obtain them.

3) They can provide benefits for the company. The more profits for the company due to the use of certain resources, the more valuable said resources are.

4) They are durable.

(Penrose in Kor \& Mahoney 2004; Acedo et al., 2006).

In line with the views of the RBV theory, intellectual capital is now considered the resource that can facilitate the achievement of goals. According to Pulic (1998), Firer and Williams (2003), Chen et al., (2005), Mavridis and Kyrmizoglou (2005), Kamath (2008) and Bontis (2010).

In terms of accounting and finance, the measurement of IC was formulated by Pulic (1998). According to him, IC measurement uses VAIC (Value Added Intellectual Capital), which is the sum of VACA (Value Added Capital Employed), VAHU (Value Added Human Capital), and STVA (Structural Capital Value Added). VACA is an indicator of VA (Value Added) created by a unit of physical capital. This ratio represents the contribution of each unit of CE (Capital Employed) to the value added of the organization. In turn, VAHU defines how much VA can be generated with funds spent on labor. This ratio indicates the contribution of each rupiah invested in Human Capital to the value added of the organization. Finally, STVA shows the number of Service Companies needed to produce 1 rupiah from VA and is an indicator of how successful SCs are at creating value.

Several authors have proven that VAIC and each of its components influence company performance; they include Firer and Williams (2003), Chen et al. (2005), Mavridis \& Kyrmizoglou (2005), Shiu (2006), Kamath (2008), Joshi et al., (2010), Joshi et al., (2013) and Sumedrea (2013). They found that intellectual capital itself, measured through VAIC and each component of VAIC, had a significant effect on company performance as measured by ROA (Return on Assets), ROE (Return on Equity), and Operational Efficiency Ratio (OER). Thus, it can be concluded that the presence of IC not only has an impact on profitability but also on bank efficiency. 
The efficiency of banks in Indonesia could benefit from a comparison between operating expenses and operating income. The lower the BOPO the more efficient the operational costs of the bank under analysis and the lower the possibility of problematic conditions for the financial institution (Lukman, 2009). Based on the conceptual description of intellectual capital and bank efficiency above, we developed the following hypotheses.

$\mathrm{H}_{1}$ : VAIC has a significant effect on bank efficiency.

$\mathrm{H}_{1.1}$ : VACA has a significant effect on bank efficiency.

$\mathrm{H}_{1.2}$ : VAHU has a significant effect on bank efficiency.

$\mathrm{H}_{1.3}$ : STVA has a significant effect on bank efficiency.

The formulation developed by Pulic has encouraged researchers in several countries to conduct research assessing intellectual capital associated with company performance as measured by financial instruments. The results of their research showed that intellectual capital measured through VAIC and each component of VAIC itself had a significant influence on company performance as measured by ROA (Return on Assets), ROE (Return on Equity), NPL (Non-Performing Loans), LDR (Loan to Deposit Ratio), CAR (Capital Adequacy Ratio), and bank efficiency (BOPO). Thus, it can be concluded that the presence of IC not only has an impact on the profitability of companies because, in the banking sector, it also influences liquidity, bank adequacy, and efficiency.

Regarding the interpretation of VAIC itself, Kamath (2008) classified companies based on VAIC values into four groups: bad performers, common performers, good performers, and top performers. According to him, a company is a bad performer if its VAIC value is below 2.5. Such value would indicate that the use of intellectual capital in the company is still very limited because each IC component only produces a value added under $\$ 2.5$ for the company. Bad performers are generally companies with high infrastructure costs, high social obligations, massive work force, poor image, low efficiency, and poor technology use.

Common performers have a VAIC between 2.5 and 4. This value indicates that each IC component can produce a value added between 2.5 and 4 rupiahs and that, in general, the company is unable to utilize IC to produce maximum value added. Common performers are characterized by the average efficiency of their workers and less technology applied to products.

Good performers exhibit a VAIC between 4.1 and 5. Such VAIC indicates that the company is able to manage most of its ICs to produce added value for the company, and each IC component can produce an added value above 4 rupiahs on average. Good performers are characterized by high appreciation of knowledge by workers, technology-based products, good customer relations, and broad markets.

Top performers have a VAIC above 5. This value indicates that the company has managed its intellectual capital very well, and each IC component can produce a value added for the company over $\$ 5$. Companies in this group are highly technology intensive, carry out only specialized activities employing trained workers, and manufacture specific high-value customized products.

According to some current authors, IC (measured using VAIC) is related to risk governance. MacDougall and Hurst (2005) argue that the development of bank employees' knowledge can provide improvements in terms of expertise and stimulation of creativity. The benefits of developing 
intellectual capital are increasingly experienced in the lower levels of management where, thanks to product and process improvement and innovation as well as operational efficiency, managers do not perceive much risk or experience substantial economic losses.

The relationship between IC and risk has also been explored by Jafari et al., (2011). They claim that measurements of ICs can be part of a company's efforts to manage risk adequately. Risk management requires an integration between innovation, human capital, and knowledge, all of which are measured using IC size. The integration of IC into company risk management has an impact on the improvement of company performance.

Banks can also use IC as a reference point to make credit decisions (Cabrita \& Bontis, 2008). Iazzolino et al., (2013) modeled credit valuation using multiple discriminant analyses. They concluded that the ability of human resources as an intangible asset in a company, represented by IC, can be an important aspect that banks should consider to grant credits. The condition of the IC at a company reflects how much risk the bank will face as a result of lending funds to said company.

Mollabashi and Sendani (2014) and Bayraktaroglu et al., (2019) explain that intellectual capital (as measured by VAIC) and each component of VAIC (such as human capital, structural capital, and relational capital) have an influence on the risk of corporate bankruptcy. Thus, it can be concluded that intellectual capital is a must-have capital for companies in order to counteract the various risks that will be faced, including maintaining the sustainability of the company. Various conceptual descriptions and results in previous studies show that operational risk can be prevented through the provision of adequate IC, represented by VAIC. IC ownership by banks is believed to be able to contribute to controlling banks' operational risk, which can threaten the sustainability of bank activities.

\section{Bank Size and Bank Efficiency}

The structure-conduct-performance (SCP) paradigm has provided guidance for banking practices. According to it, assets are input factors that become the bargaining power of banks and determine how banks behave which, in turn, will determine their performance (Neuberger, 1998). In line with this theory, the concept of asset and liability management further highlights the need for good bank asset management, where according to the concept banking assets are the side of the use of funds by banks related to fund fertilization in the form of first, second, and third-party funds (Riyadi, 2006).

Riyadi (2006) categorized bank assets into sensitive assets and fixed rate assets. Sensitive assets present a relatively short placement period, and changes in interest rates will directly affect them. Sensitive assets include secondary reserves, such as call money placement, money market securities, Bank Indonesia certificates, and stocks/bonds; and short-term loans (i.e., granted with a maturity of less than a year), such as working capital loans or overdraft loans to cover a customer's account balance due to clearing. Fixed rate assets are placed with a period over a year and a fixed rate. They include long-term loans (i.e., loans granted for more than a year, usually in the form of investment loans) and investment participation (both directly and indirectly), where securities are not used for trading but for long-term investment purposes. 
Therefore, banks should assign funds to assets cautiously because, for every decision to allocate funds to a group of sensitive or fixed rate assets, they need to ponder on the risks of each asset so that it does not have a negative impact on bank losses in the short or long term (Beck et al., 2013; Fiordelisi \& Mare, 2014; Jeon \& Lim, 2013; Soedarmono et al., 2013).

Banks with larger assets should behave efficiently if they want to increase profitability (Albertazzi \& Gambacorta, 2009). Alhassan and Ohene-Asare (2016) proved that Significant assets owned by banks have a positive effect on bank efficiency. This means that the greater the assets owned by the bank to carry out its operations, the more efficient the bank should be. This is because, if banks manage their assets efficiently, they can avoid any loss. In other words, large banks are "too big to fail" and should increase efficiency as they grow. (Doan et al., 2018). The Operational Efficiency Ratio can be used to prove banks' ability to manage assets efficiently. The better the Operational Efficiency Ratio value, the better the asset management by banks as a means to increase operating income.

\section{METHOD}

Based on the literature review of bank size and bank efficiency above, we developed an additional hypothesis:

$\mathrm{H}_{2}$ : Bank size has a significant effect on bank efficiency.

\section{Market Share and Bank Efficiency}

As cited by Widyastuti and Armanto (2013), Alhadeff described five characteristics of the banking market. First, the presence of more than one credit provider. Second, the relationship between the banker and the borrower (debtor) is built on experiences related to credit distribution in the past. Third, large volumes of credit borrowers receive more loan offers while small numbers of borrowers face very limited supply. Fourth, there are obstacles to the entry of new players, which indicates a tendency to maintain a monopoly or oligopoly in order to obtain positive benefits in the long run. Fifth, bankers' actions or decisions are generally correlated, which is often referred to as agreement, mutual assistance, reduction of unhealthy competition, coordination, etc.

The structure-conduct-performance (SCP) paradigm holds that market structure can determine bank behavior which, in turn, has implications for achieving performance. Empirically, the existence of a positive relationship between market structure and performance has been proven in Berger and Hannan's (1998) study, which found that a banking industry with an oligopolistic market structure tends to achieve optimal performance. This shows that banks with an oligopolistic market structure certainly have the optimal ability to control a larger market and indirectly gain greater economic benefits. However, that study did not explore the behavior of banks in oligopolies.

Bawono and Prestianawati (2019), in the study entitled Rethinking of Finance Stability, reveal the stability of the internal value of money or the exchange rate of money for goods from any form of money transformation, so this research will help people to decide which money they should choose to do profitable investment. This result also help government to make alternative policy consideration for countries in the world especially developing countries in deciding the form of 
money they should invest. Their study will help people decide which financial instrument they should choose to make profitable investments. These results also help the government to consider alternative policies for different countries around the world, especially developing ones, in order to decide on the form of money they must invest in. The focus of research in the field of money transformation should shift to the digital-based global financial systemin order to investigate the transformation of money from paper-based to computer-based.

"Rastin Banking complies with the nature of financial intermediary activity (partnership of depositor in the yields of the fund receiver via the bank). In order to fulfil this goal, particular formation, organisational structure, instruments and workflow are defined in a legal framework" (Bidabad, 2018).

Claessens and Laeven (2004) found that high competition in the financial sector can encourage better production efficiency, financial product quality, and level of innovation. Increased competition is also expected to reduce the cost of intermediation services in order to be more efficient because the time needed to manage loans is much shorter and will ultimately increase bank revenues (Di Patti \& Dell'Ariccia, 2004).

Based on the conceptual description of market structure and bank efficiency above, we propose the following hypothesis:

$\mathrm{H}_{3}$ : Market share has a significant effect on bank efficiency.

In order to analyze the intellectual capital variables (bank size, market structure, and bank efficiency), the present study used a panel data regression analysis of 82 commercial banks in Indonesia observed between 2013 and 2017. The measurement of the variables under study is detailed below in Table 1.

Table 1. Variable operationalization

Tabla 1. Operacionalización de las variables

\begin{tabular}{|c|c|c|c|}
\hline Variable & Dimension & Indicator & Data Scale \\
\hline Independent: & & & \\
\hline Bank Efficiency & Input & 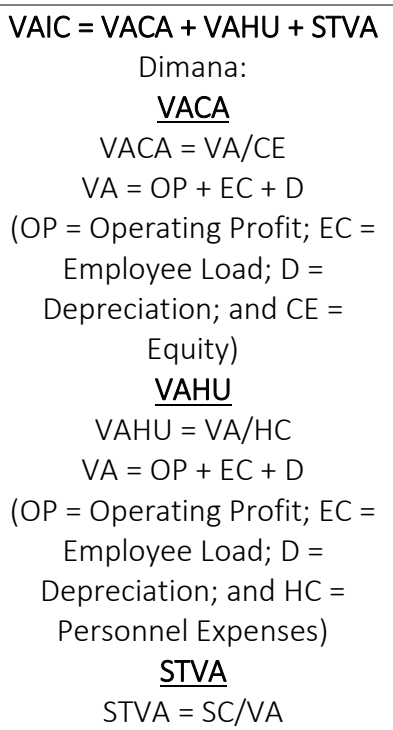 & Ratio \\
\hline
\end{tabular}




\begin{tabular}{|c|c|c|c|}
\hline & & $\begin{array}{c}\mathrm{SC}=\mathrm{VA}-\mathrm{HC} \\
\mathrm{VA}=\mathrm{OP}+\mathrm{EC}+\mathrm{D} \\
(\mathrm{OP}=\text { Operating Profit; } \mathrm{EC}= \\
\text { Employee Load; } \mathrm{D}= \\
\text { Depreciation; and } \mathrm{HC}= \\
\text { Personnel Expenses })\end{array}$ & \\
\hline & & Number of ATMs & Ratio \\
\hline & & $\begin{array}{l}\text { Amount of Third-Party } \\
\text { Funds }\end{array}$ & Ratio \\
\hline & Output & Credit Amount & Ratio \\
\hline & & The amount of income & Ratio \\
\hline Bank size (ASSET) & Ln Total Assets & $\begin{array}{c}\text { (Ab-Hamid et al. 2017; } \\
\text { Alhassan \& Ohene-Asare, } \\
\text { 2016; Delis \& Papanikolaou, } \\
\text { 2009) }\end{array}$ & Balance sheet \\
\hline Market share (SHAR) & $\begin{array}{c}\text { Bank Loan i/Total } \\
\text { Loan }\end{array}$ & $\begin{array}{c}\text { (Ab-Hamid et al., 2017; } \\
\text { Alhassan \& Ohene-Asare, } \\
\text { 2016; Nguyen, 2018) }\end{array}$ & Balance sheet \\
\hline
\end{tabular}

The research model with panel data developed in this study is written as follows.

\section{Model 1}

$$
B O P O_{i, t}=b_{0}+b_{1} V A I C_{i, t}+b_{2} A_{S E T} i, t+b_{3} S H A R_{i, t}+e_{i, t}
$$

Where:

BOPOi, $t=$ Bank efficiency $i$ in period $t$,

$\mathrm{VAICi}, \mathrm{t}=$ Intellectual capital of bank $\mathrm{i}$ in period $\mathrm{t}$,

ASETi, $t=$ Natural logarithm of total bank assets $i$ in period $t$,

SHARi, $\mathrm{t}=$ Bank market share $\mathrm{i}$ in period $\mathrm{t}$,

$\mathrm{e}_{\mathrm{i}, \mathrm{t}}=$ error bank term $\mathrm{i}$ in period $\mathrm{t}$.

\section{Model 2}

$$
B O P O_{i, t}=b_{0}+b_{1} V_{A C A_{i, t}}+b_{2} V A H U_{i, t}+b_{3} S T V A_{i, t}+b_{4} A S E T_{i, t}+b_{5} S H A R_{i, t}+e_{i, t}
$$

Where:

BOPOi, $t=$ Bank efficiency $i$ in period $t$,

VACAi, $\mathrm{t}=$ Value Added Capital Employed by bank $\mathrm{i}$ in period $\mathrm{t}$,

VAHUi, $\mathrm{t}=$ Value Added Human Capital by bank $\mathrm{i}$ in period $\mathrm{t}$,

STVAi, $\mathrm{t}=$ Bank's Structural Value Added in period $\mathrm{t}$,

ASETi, $t=$ Natural logarithm of total bank assets $i$ in period $t$,

SHARi, $\mathrm{t}=$ Bank market share $\mathrm{i}$ in period $\mathrm{t}$,

$\mathrm{e}_{\mathrm{i}, \mathrm{t}}=$ error term of bank $\mathrm{i}$ in period $\mathrm{t}$.

The main objective of this study is to develop a model of bank efficiency using the SFA and DFA approaches and, then, estimate (with both methods) the effect of efficiency on the bank stability variable. In line with the objectives, we used two methods, namely, descriptive and causal research. 
The descriptive approach seeks to explain the empirical facts from the object under study based on the research data obtained (Chan et al., 2004). In turn, causal research aims to explain the causal relationship between the variables under study.

\section{Variable Operationalization}

The independent and dependent variables in the hypotheses developed in Section 2 will be empirically tested as follows:

\section{Population and Samples}

The unit of analysis in this study is commercial banks and the population is composed of conventional and shari'ah commercial banks. All these commercial banks were registered with the Financial Services Authority (OJK) between 2006 and 2017 and listed in the Commercial Bank Publication Financial Report on the OJK website.

The population and samples were grouped based on their core capital into four BUKU (Commercial Bank Based on Business Activities) groups applying the following criteria:

1. Core Capital < Rp. 1 trillion: BUKU I

2. Rp. 1 trillion Inti Core Capital < Rp.5 trillion: BUKU II

3. Rp 5 trillion $\leq$ Core Capital < Rp 30 trillion: BUKU III

4. Core Capital $\geq$ Rp. 30 trillion: BUKU IV

(Peraturan Bank Indonesia Nomor 14/26, 2012).

\section{RESULTS}

The test results of Fixed Effect Panel Regression Model 1 can be used to explain bank efficiency from the perspective of intellectual capital, bank size, and bank concentration. This model shows that the year-to-year effect of independent variables is influenced by individual bank differences. (see Table 2 and 3$)$.

Table 2. Output of Fixed Effect Panel Data Regression Model 1

Tabla 2. Resultados del Modelo 1 de regresión con datos de panel con efectos fijos

\begin{tabular}{ccccc}
\hline Variable & Coefficient & Std. Error & t-Statistic & Prob. \\
\hline C & 79.10465 & 5.680806 & 13.9249 & 0 \\
\hline VAIC & -0.55624 & 0.014676 & -37.9005 & 0 \\
\hline ASET & -2.07161 & 0.336701 & -6.15267 & 0.0457 \\
\hline SHARE & -0.105623 & 0.05265 & -2.00615 & \\
\hline Cross-section fixed (dummy variables) & Effects Specification & & \\
\hline
\end{tabular}




\begin{tabular}{llll}
\hline R-squared & 0.975383 & Mean dependent var & 267.9699 \\
\hline Adjusted R-squared & 0.96902 & S.D. dependent var & 226.2633 \\
\hline S.E. of regression & 7.435473 & Sum squared resid & 17968.03 \\
\hline F-statistic & 153.3009 & Durbin-Watson stat & 1.966779 \\
\hline Prob(F-statistic) & 0 & & \\
\hline & \multicolumn{2}{c}{ Unweighted Statistics } & 85.86276 \\
\hline R-squared & 0.877369 & Mean dependent var & 2.03978 \\
\hline Sum squared resid & 19151.07 & Durbin-Watson stat &
\end{tabular}

Table 3. Output of Fixed Effect Panel Data Regression Model 2

Tabla 3. Resultados del Modelo 2 de regresión con datos de panel con efectos fijos

Dependent Variable: BOPO

\begin{tabular}{|c|c|c|c|c|}
\hline Variable & Coefficient & Std. Error & t-Statistic & Prob. \\
\hline $\mathrm{C}$ & 134.468 & 13.05006 & 10.30401 & 0 \\
\hline VACA & -13.8768 & 1.476568 & -9.39801 & 0 \\
\hline VAHU & 0.573856 & 0.013917 & 41.23329 & 0 \\
\hline STVA & -32.6422 & 12.39345 & -2.63383 & 0.0088 \\
\hline ASET & -0.98242 & 0.240388 & -4.08681 & 0.0001 \\
\hline SHARE & -0.13483 & 0.009217 & -14.6274 & 0 \\
\hline \multicolumn{5}{|c|}{ Effects Specification } \\
\hline \multicolumn{5}{|c|}{ Cross-section fixed (dummy variables) } \\
\hline \multicolumn{5}{|c|}{ Weighted Statistics } \\
\hline R-squared & 0.994671 & \multicolumn{2}{|c|}{ Mean dependent var } & 332.8031 \\
\hline Adjusted R-squared & 0.993252 & \multicolumn{2}{|c|}{ S.D. dependent var } & 467.5631 \\
\hline S.E. of regression & 7.057711 & \multicolumn{2}{|c|}{ Akaike info criterion } & 5.081633 \\
\hline Sum squared resid & 16089.04 & \multicolumn{2}{|c|}{ Schwarz criterion } & 5.933842 \\
\hline Log likelihood & -954.735 & \multicolumn{2}{|c|}{ Hannan-Quinn criter. } & 5.41879 \\
\hline F-statistic & 701.0701 & \multicolumn{2}{|c|}{ Durbin-Watson stat } & 1.948339 \\
\hline \multicolumn{5}{|l|}{ Prob(F-statistic) } \\
\hline \multicolumn{5}{|c|}{ Unweighted Statistics } \\
\hline R-squared & 0.896975 & \multicolumn{2}{|c|}{ Mean dependent var } & 85.86276 \\
\hline Sum squared resid & 16089.21 & \multicolumn{2}{|c|}{ Durbin-Watson stat } & 2.077325 \\
\hline
\end{tabular}

Source: Results of processing by EViews, 2018 


\section{DISCUSSION}

Table 2 shows the value of the R-square model of the first test. It indicates that the simultaneous effect of the independent variables on the dependent variable is very strong ( $97.54 \%$ ), and $2.46 \%$ is influenced by other variables. The existence of said strong effect also shows that the three independent variables under studied are the dominant variables that affect changes in bank efficiency.

Intellectual capital proxied by VAIC shows that intellectual capital can partially improve bank efficiency. However, it can be seen that larger numbers of assets actually make banks more inefficient. When viewed from the perspective of market share, credit market share has a positive effect on efficiency. This shows that, as a result of greater market dominance, banks operate efficiently.

The positive effect of intellectual capital proxied by VAIC indicates that high intellectual capital encourages banks to behave efficiently. This is in line with the research findings of Joshi et al., (2013). They explained that financial sector companies need to invest in the development of human resources, organizational processes, and the company's knowledge base to gain sustainable competitive advantage. In addition, in recent years, financial sector companies have begun to explore the benefits offered by new client-oriented organizational forms and by implementing new managerial control systems. For that reason, IC and knowledge management have emerged as core competencies for company growth and protecting competitive advantage. The growth of servicebased industries has increased the emphasis on employee knowledge and creativity as means to add value to businesses, highlighting an important need for IC measurement and management.

Some findings show the positive effect of intellectual capital on efficiency in banking in Indonesia. In accordance with the Surat Keputusan Direksi Bank Indonesia Nomor 31/310/1999 (Decree of the Board of Directors of Bank Indonesia Number 31/310/KEP/DIR/1999) concerning the Provision of Funds for Human Resource Development of Commercial Bank, Paragraph (1) Article 2, banks are required to provide education funds to improve the knowledge and skills of human resources in banking management; this includes the fields of operations, marketing, and bank management, among others.

In addition to intellectual capital, bank size was found to have a negative effect on bank efficiency. This shows that greater total assets owned by commercial banks in Indonesia make them unable to operate efficiently. This finding contradicts those of Heryana and Saputra (2013), Joshi et al., (2013), and Sumedrea (2013), who reported that companies with large assets are encouraged to behave even more efficiently.

These negative effects of asset size on bank efficiency further support the idea that, in the era of digital banking services, the need for physical assets has shifted towards intangible assets, such as intellectual capital. This is in line with the theory of RBV, where the necessary resources have several characteristics. 
The present study also found that market share has a positive effect on bank efficiency. This means that, when banks have a greater market share, they are encouraged to behave more efficiently. This is in line with the view of Claessens and Laeven (2004).

This finding also supports the SCP theory, which explains the linear relationship between market share and bank behavior. Banks can certainly obtain economic benefits if they are able to carry out their operations in an efficient way.

In addition to describing how efficiency changes are seen from VAIC as a whole, this study also defines how each component in VAIC affects bank efficiency, bank size, and bank market structure. The results of the panel data regression analysis with EViews in Model 2 are detailed below.

Table 3 shows that each component of intellectual capital (i.e., VACA, VAHU, and STVA) has a significant effect on bank efficiency. VACA, a representation of physical capital, has a negative effect on efficiency. This shows that physical capital creates a large burden if banks are not able to manage it. A large burden combined with management inability will make a bank inefficient.

VAHU shows how much value added is generated from the funds spent on employees. Table 3 indicates that VAHU has a positive effect on bank efficiency. Therefore, banks should allocate funds for employee education and training so that their employees have adequate knowledge to do their work. Increased employee knowledge will certainly benefit banks in order to increase efficiency.

STVA represents the value added generated if, while carrying out their work activities, employees have the ability to build good networks, which refer to networking between employees and relationships with consumers and stakeholders. According to Sumedrea (2013), to build networks that have pre-conditions, employees must have adequate knowledge. In other words, in the context of intellectual capital, STVA requires VAHU.

As can been seen in Table 3, bank size and market share produce the same results; they are equally significant and have a negative impact. Thus, it can be concluded that Models 1 and 2 do not exhibit a meaningful change when the VAIC model is calculated as a whole or partially per component. This is in line with the findings of researchers in the field of intellectual capital who conducted 2-stage modeling, including Clarke et al., (2011), Firer and Williams (2003), Chen Goh and Pheng Lim (2004), Mavridis and Kyrmizoglou (2005) and Ulum et al., (2008).

\section{CONCLUSIONS}

Three conclusions can be drawn from the findings of the present study and the results of the panel data analysis of Models 1 and 2:

1. The panel data analysis of the first model reports a significant effect of intellectual capital, bank size, and market share on the efficiency of commercial banks in Indonesia.

2. The second model shows a significant effect of VACA, VAHU, STVA, bank size, and market share on the efficiency of commercial banks in Indonesia. 
3. The first and second models show no difference in the effects on independent variables when intellectual capital is calculated as a whole or only analyzed individually per component.

The results of this study indicate that intellectual capital and its components consistently affect bank efficiency. The company size and market share of banks also have the same effect.

Consequently, banks should make continuous efforts to improve their human resources and develop employee knowledge as much as possible with measurable effects on the output of their work. Likewise, banks with large assets need to pay attention to the optimization of assets so that they do not have implications for the operational burden on the bank. This study also opens up some opportunities for further studies to examine the interaction of intellectual capital, bank size, and market share in relation to bank efficiency. This study also opens up some opportunities for further studies to examine the interaction of intellectual capital, bank size, and market share in relation to bank efficiency measured using methods such as Data Envelopment Analysis (DEA).

\section{REFERENCES}

Ab-Hamid, M. F., Abdul-Rahman, A., Abdul-Majid, M., \& Janor, H. (2017). Bank Market Risk and Efficiency of Commercial Banks in Malaysia. Jurnal Pengurusan, 51, 249-259. URL

Acedo, F. J., Barroso, C., \& Galan, J. L. (2006). The resource-based theory: dissemination and main trends. Strategic Management Journal, 27(7), 621-636. https://doi.org/10.1002/smj.532

Albertazzi, U., \& Gambacorta, L. (2009). Bank profitability and the business cycle. Journal of Financial Stability, 5(4), 393-409. https://doi.org/10.1016/j.jfs.2008.10.002

Alhassan, A. L., \& Ohene-Asare, K. (2016). Competition and bank efficiency in emerging markets: empirical evidence from Ghana. African Journal of Economic and Management Studies, 7(2), 268-288. https://doi.org/10.1108/AJEMS-01-2014-0007

Allen, F., \& Santomero, A. M. (1997). The Theory of Financial Intermediation. Journal of Banking \& Finance, 21(11-12), 1461-1485. https://doi.org/10.1016/S0378-4266(97)00032-0

Astiyah, S., \& Husman, J. A. (2006). Fungsi Intermediasi Dalam Efisiensi Perbankan Di Indonesia: Derivasi Fungsi Profit. Buletin Ekonomi Moneter dan Perbankan, 8(4), 529-544. https://doi.org/10.21098/bemp.v8i4.148

Bawono, S., \& Prestianawati, S. A. (2019). Rethinking of finance stability: Gold, fiat money and anticrypto money policy puzzle impact in stability of internal value. Journal of Business and Finance in Emerging Markets, 2(1), 15-22. https://doi.org/10.32770/jbfem.vol215-22

Bayraktaroglu, A. E., Calisir, F., \& Baskak, M. (2019). Intellectual capital and firm performance: An extended VAIC model. Journal of Intellectual Capital, 20(3), 406-425. https://doi.org/10.1108/JIC-12-2017-0184 
Beck, T., Demirgüç-Kunt, A., \& Merrouche, O. (2013). Islamic vs. conventional banking: Business model, efficiency and stability. Journal of Banking and Finance, 37(2), 433-447. https://doi.org/10.1016/j.jbankfin.2012.09.016

Berger, A. N., \& Hannan, T. H. (1998). The Efficiency Cost of Market Power in the Banking Industry: A Test of the "Quiet Life" and Related Hypotheses. The Review of Economics and Statistic, 80(3), 454-465. https://doi.org/10.1162/003465398557555

Bidabad, B. (2018). General regulatory framework in rastin profit and loss sharing banking (part Ioperational context), Journal of Business and Finance in Emerging Markets, 1(1), 11-26. https://doi.org/10.32770/jbfem.vol111-26

Bontis, N. (2010). Assessing knowledge assets: a review of the models used to measure intellectual capital. International Journal of Management Reviews, 3(1), 41-60. https://doi.org/10.1111/1468-2370.00053

Cabrita, M. D. R., \& Bontis, N. (2008). Intellectual capital and business performance in the Portuguese banking industry. International Journal of Technology Management, 43(1-3), 212-237. https://doi.org/10.1504/IJTM.2008.019416

Chan, W. S., Frankel, R., \& Kothari, S. P. (2004). Testing behavioral finance theories using trends and consistency in financial performance. Journal of Accounting and Economics, 38, 3-50. https://doi.org/10.1016/j.jacceco.2004.07.003

Chen, M. C., Cheng, S. J., \& Hwang, Y. (2005). An Empirical Investigation of the Relationship between Intellectual Capital and Firms' Market Value and Financial Performance. Journal of Intellectual Capital, 6(2), 159-176. https://doi.org/10.1108/14691930510592771

Chen Goh, P., \& Pheng Lim, K. (2004). Disclosing intellectual capital in company annual reports: Evidence from Malaysia. Journal of Intellectual Capital, 5(3), 500-510. https://doi.org/10.1108/14691930410550426

Claessens, S., \& Laeven, L. (2004). What Drives Bank Competition? Some International Evidence. Journal of Money, Credit and Banking, 36(3), 563-583. URL

Clarke, M., Seng, D., \& Whiting, R. H. (2011). Intellectual capital and firm performance in Australia. Journal of Intellectual Capital, 12(4), 505-530. https://doi.org/10.1108/14691931111181706

Delis, M. D., \& Papanikolaou, N. I. (2009). Determinants of bank efficiency: evidence from a semiparametric methodology. Managerial Finance, 35(3), 260-275. https://doi.org/10.1108/03074350910931771

Di Patti, E. B., \& Dell'Ariccia, G. (2004). Bank Competition and Firm Creation. Journal of Money, Credit and Banking, 36(2), 225-251. URL 
Doan, A. T., Lin, K. L., \& Doong, S. C. (2018). What drives bank efficiency? The interaction of bank income diversification and ownership. International Review of Economics \& Finance, 55, 203219. https://doi.org/10.1016/j.iref.2017.07.019

Faruk, U., Disman, D., \& Nugraha, N. (2017). Efficiency and Productivity Growth Analysis of the Islamic Banking in Indonesia Data Envelopment Analysis and Malmquist Productivity Index Approach. In International Conference on Islamic Economics, Business and Philanthropy. SCITEPRESS. https://doi.org/10.5220/0007079502130218

Fiordelisi, F., \& Mare, D. S. (2014). Competition and financial stability in European cooperative banks. Journal of International Money and Finance, 45, 1-16. https://doi.org/10.1016/i.jimonfin.2014.02.008

Firer, S., \& Williams, S. M. (2003). Intellectual capital and traditional measures of corporate performance. Journal of Intellectual Capital, 4(3), 348-360. https://doi.org/10.1108/14691930310487806

Girardone, C., Molyneux, P., \& Gardener, E. P. M. (2004). Analysing the determinants of bank efficiency: the case of Italian banks. Applied Economics, 36(3), 215-227. https://doi.org/10.1080/0003684042000175334

Heryana, T., \& Saputra, R. I. (2013). Implikasi Modal Intelektual terhadap Kinerja Keuangan (Studi Empiris pada Perbankan di Bursa Efek Indonesia). In Forum Keuangan dan Bisnis /I (pp. 1-11). Bandung: Laboratorium Akuntansi Program Studi Akuntansi.

Iazzolino, G., Migliano, G., \& Gregorace, E. (2013). Evaluating intellectual capital for supporting credit risk assessment: An empirical study. Investment Management and Financial Innovations, 10(2), 44-54. URL

Jafari, M., Rezaeenour, J., Mahdavi Mazdeh, M., \& Hooshmandi, A. (2011). Development and evaluation of a knowledge risk management model for project-based organizations: A multistage study. Management Decision, 49(3), 309-329. https://doi.org/10.1108/00251741111120725

Jeon, J. Q., \& Lim, K. K. (2013). Bank competition and financial stability: A comparison of commercial banks and mutual savings banks in Korea. Pacific-Basin Finance Journal, 25, 253-272. https://doi.org/10.1016/j.pacfin.2013.10.003

Joshi, M., Cahill, D., \& Sidhu, J. (2010). Intellectual capital performance in the banking sector: An assessment of Australian owned banks. Journal of Human Resource Costing \& Accounting, 14(2), 151-170. https://doi.org/10.1108/14013381011062649

Joshi, M., Cahill, D., Sidhu, J., \& Kansal, M. (2013). Intellectual capital and financial performance: an evaluation of the Australian financial sector. Journal of Intellectual Capital, 14(2), 264-285. https://doi.org/10.1108/14691931311323887 
Kamath, G. B. (2008). Intellectual capital and corporate performance in Indian pharmaceutical industry. Journal of Intellectual Capital, 9(4), 684-704. https://doi.org/10.1108/14691930810913221

Kegiatan usaha dan jaringan kantor berdasarkan modal inti bank, PIB. 14/26 (2012). URL

Kor, Y. Y., \& Mahoney, J. T. (2004). Edith Penrose's (1959) Contributions to the Resource-Based View of Strategic Management. Journal of Management Studies, 41(1), 183-191. https://doi.org/10.1111/j.1467-6486.2004.00427.x

Lukman, D. (2009). Manajemen Perbankan (3rd Ed.). Ghalia Indonesia.

Mavridis, D. G., \& Kyrmizoglou, P. (2005). Intellectual capital performance drivers in the Greek banking sector. Management Research News, 28(5), 43-62. https://doi.org/10.1108/01409170510629032

MacDougall, S. L., \& Hurts, D. (2005). Identifying tangible costs, benefits and risks of an investment in intellectual capital: Contracting contingent knowledge workers. Journal of Intellectual Capital, 6(1), 53-71. https://doi.org/10.1108/14691930510574663

Mollabashi, D. F., \& Sendani, J. (2014). The Impact of Intellectual Capital on The Risk of Bankruptcy of the Listed Companies in Tehran Stock Exchange. Indian Journal Science Research, 7(1), 105113. URL

Neuberger, D. (1998). Industrial Organization of Banking: A Review. International Journal of the Economics of Business, 5(1), 97-118. https://doi.org/10.1080/13571519884594

Newbert, S. L. (2007). Empirical Research on the Resource-Based View of the Firm: An Assessment and Suggestions for Future Research. Strategic Management Journal, 28(2), 121-146. https://doi.org/10.1002/smj.573

Nguyen, T. L. A. (2018). Diversification and bank efficiency in six ASEAN countries. Global Finance Journal, 37, 57-78. https://doi.org/10.1016/i.gfj.2018.04.004

Peraturan Bank Indonesia Nomor 14/26/PBI/2012. (2012). URL

Pulic, A. (1998). Measuring the Performance of Intellectual Potential in Knowledge Economy. In 2nd McMaster World Congress on Measuring and Managing Intellectual Capital (pp. 1-20). URL

Riyadi, S. (2006). Banking Assets and Liability Management (3rd Ed.). Publisher Institution FE UI.

Rugman, A. M., \& Verbeke, A. (2002). Edith Penrose's contribution to the resource-based view of strategic management. Strategic Management Journal, 23(8), 769-780. https://doi.org/10.1002/smj.240

Salem, S. M., \& Rahman, N. A. (2016). The effect of bank-specific factors and unstable macroeconomic 
environment on bank efficiency: evidence from FCC. International Journal of Advanced and Applied Sciences, 3(9), 97-102. https://doi.org/10.21833/ijaas.2016.09.014

Shaban, M., Duygun, M., Anwar, M., \& Akbar, B. (2014). Diversification and Banks' Willingness to Lend to Small Businesses: Evidence from Islamic and Conventional Banks in Indonesia. Journal of Economic Behavior \& Organization, 103, 39-55. https://doi.org/10.1016/j.jebo.2014.03.021

Shiu, H. J. (2006). The Application of the Value Added Intellectual Coefficient to Measure Corporate Performance: Evidence from Technological Firms. International Journal of Management, 23(2), 356-365. URL

Soedarmono, W., Machrouh, F., \& Tarazi, A. (2013). Bank competition, crisis and risk taking: Evidence from emerging markets in Asia. Journal of International Financial Markets, Institutions and Money, 23, 196-221. https://doi.org/10.1016/j.intfin.2012.09.009

Song, H., Yu, K., \& Lu, Q. (2018). Financial service providers and banks' role in helping SMEs to access finance. International Journal of Physical Distribution \& Logistics Management, 48(1), 69-92. https://doi.org/10.1108/IJPDLM-11-2016-0315

Sudarsono, H. (2009). The Impact of the Global Financial Crisis on Banking in Indonesia: Comparison between Conventional Banks and Islamic Banks. Journal of Islamic Economics Lariba, 3(1), 1223.

Sumedrea, S. (2013). Intellectual Capital and Firm Performance: A Dynamic Relationship in Crisis Time. Procedia Economics and Finance, 6(13), 137-144. https://doi.org/10.1016/S2212$\underline{5671(13) 00125-1}$

Surat Keputusan Direksi Bank Indonesia, KEP/DIR. 31/310. (1999).

Ulum, I., Ghozali, I., \& Chariri, A. (2008). Intellectual capital dan kinerja keuangan perusahaan; suatu analisis dengan pendekatan partial least squares (PLS). In Simposium Nasional Akuntansi. URL

Widyastuti, R. S., \& Armanto, B. (2013). Banking Industry Competition in Indonesia. Bulletin of Monetary and Banking Economics, 15(4), 1-34. https://doi.org/10.21098/bemp.v15i4.433 